\title{
Anti-HIV-1 activity of Sargassum swartzii a marine brown alga
}

\author{
Dinesh Subramaniam", Thangam Menon ${ }^{1 *}$, Hanna Luke Elizabeth², Soumya Swaminathan ${ }^{2}$ \\ From 2nd International Science Symposium on HIV and Infectious Diseases (HIV SCIENCE 2014) \\ Chennai, India. 30 January - 1 February 2014
}

\section{Background}

Currently available antiretrovirals are relatively expensive and have side effects. Hence, there is need to develop novel drugs against HIV. The present study was planned to investigate the anti-HIV activity of extracts of the marine brown algae Sargassum swartzii.

\section{Methods}

The HIV inhibitory activity of aqueous and methanolic extracts of $S$. swartzii was determined on laboratory adapted strains of HIV-1 clades $\mathrm{C}$ and A by indirectly measuring reduction in HIV-1 gag p24 antigen levels and inhibition of HIV-1 RT activity in supernatants of virus infected donor peripheral blood mononuclear cell (PBMC) cultures grown in varying concentrations of the extracts. Phytochemical analysis and cytotoxicity of the extracts was also undertaken.

\section{Results}

Results showed that both aqueous and methanolic extracts of S. swartzii had an inhibitory effect on HIV-1clade C, and the response was dose dependent. At a concentration of $0.39 \mu \mathrm{g} / \mathrm{ml}$, aqueous and methanolic extracts of $S$. swartzii demonstrated $71.1 \pm 2 \%$ and $74.7 \pm 2.9 \%$ inhibition of virus production, respectively. A similar response was observed with a HIV-1 clade A primary isolate. The extracts also showed inhibition of RT activity, and no cytotoxicity on human PBMC. Phytochemical analysis revealed that the aqueous extract of $S$. swartzii contained sulfate and uronic acid, while the methanolic extract contained hexadecanoic acid. These compounds could be responsible for the anti-HIV-1 activity.

\footnotetext{
* Correspondence: thangam56@gmail.com

'Department of Microbiology, Dr ALM PG IBMS, University of Madras,

Chennai, India

Full list of author information is available at the end of the article
}

\section{Conclusion}

S. swartzii extracts significantly inhibited HIV-1 virus suggesting that it may be useful in therapeutics. This study is the first report to show that $S$. swartzii possesses compounds with anti HIV-1 activity.

\section{Authors' details}

'Department of Microbiology, Dr ALM PG IBMS, University of Madras, Chennai, India. ${ }^{2}$ Department of Clinical Research, National Institute for research in Tuberculosis (NIRT), Chennai, India.

Published: 27 May 2014

\section{doi:10.1186/1471-2334-14-S3-E43}

Cite this article as: Subramaniam et al:: Anti-HIV-1 activity of Sargassum swartzii a marine brown alga. BMC Infectious Diseases 2014

14(Suppl 3):E43.
Submit your next manuscript to BioMed Central and take full advantage of:

- Convenient online submission

- Thorough peer review

- No space constraints or color figure charges

- Immediate publication on acceptance

- Inclusion in PubMed, CAS, Scopus and Google Scholar

- Research which is freely available for redistribution
() Biomed Central 